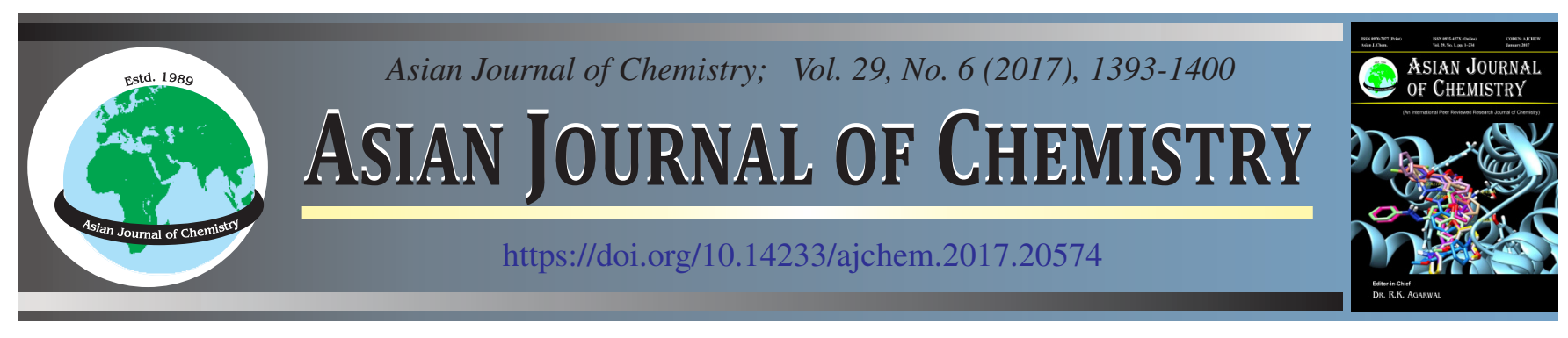

\title{
Phytochemical Investigation and Characterization of Isolated Chemical Constituents from Kyllinga triceps Rottb.
}

\author{
Nishant Verma ${ }^{1, *}$, K.K. Jha ${ }^{1}$, Shamim Ahmad ${ }^{2}$, Sudhir Chaudhary ${ }^{3}$ and Mohammad Ali ${ }^{4}$
}

${ }^{1}$ T.M. College of Pharmacy, Teerthanker Mahaveer University, Moradabad-244 001, India

${ }^{2}$ Translam Institute of Pharmaceutical Education \& Research, Meerut-250 001, India

${ }^{3}$ B.B.S. Institute of Pharmaceutical \& Allies Sciences, Knowledge Park-III, Greater Noida-201 310, India

${ }^{4}$ Faculty of Pharmacy, Jamia Hamdard University, New Delhi-110 062, India

*Corresponding author: E-mail: nishantvermamiet@gmail.com

Four compounds have been isolated by column chromatography from Kyllinga triceps namely quercetin dihydrate (1), rutin (2), $\beta$ sitosterol (3) and stigmasterol (4). Their structures have been elucidated by, FTIR, HR-EIMS, ${ }^{1} \mathrm{H}$ NMR and ${ }^{13} \mathrm{C}$ NMR spectroscopic studies.

Keywords: Column chromatography.

\section{INTRODUCTION}

Plants make a significant contribution to health care due to their recognition in traditional medicinal systems [1]. Herbal medicine are supposed to be safer than synthetic counterparts because the phytochemicals, in the plant extract, target the biochemical pathway [2]. Kyllinga triceps is a herb belonging to family Cyperaceae. It is a small genus of annual or perennial herbs, distributed in the tropical and sub tropical region of the world. About eight species occur in india. Kyllinga triceps Rottb. Is a small tufted herb, up to 12 inches high with a short rhizome and linear leaves, one half or nearly as long as the stem, found in Kumaon at altitudes of 5000-6000 ft. and from the upper gangetic plain to West Bengal, Sundarbans and Deccan Peninsula. The plant has the same vernacular name as Kyllinga monocephala [3].

Traditionally the decoction of roots is used as refrigerant, demulcent and tonic. It is given to relieve thirst in fevers and in diabetes. It is also used as antidote to poisons. Oil distilled from the root is used to relieve pruritus of the skin, internally, oil is given in torpor of the liver [4]. Synonym of Kyllinga triceps is Kyllinga tenuifolia and Cyperus triceps (Rottb.) [5]. Fresh juice of the plant is used externally to wash the wounds. It is used in the treatment of indigestion. The oil of roots is used to promote the action of liver and relieve pruritus [6]. Decoction of roots is used in diabetes and to relieve thirst in fever. The literature reveals that no isolation work by column chromatography has been done on Kyllinga triceps.
In present we wish to report some of the phyto-constituents from whole plant of Kyllinga triceps which could be regarded as the ever identified compound.

\section{EXPERIMENTAL}

Fresh plant of Kyllinga triceps was collected in the month of April, 2011 from Venkateswara University, Tirupati, India. The plant was identified and authenticated by Dr. K. Madhava Chetty, Asst. Professor, Department of Botany, Sri Venkateswara University, Tirupati, Andhra Pradesh, India. A voucher specimen has been deposited at the College of Pharmacy, TMU Moradabad (TMU/Consult/2011-12/206) for future reference.

Preparation of the extract and isolation: The air-dried whole plant of Kyllinga triceps $(1 \mathrm{~kg}$ ) was defatted with $n$-hexane and petroleum ether followed by extraction with chloroform, ethyl acetate and $n$-butanol using Soxhlet extractor [7]. The resulting extracts were tested for the presence of flavonoids by Shinoda test [8]. Ethyl acetate fraction was found to have the highest amount of flavonoids [9]. Systematic fractionation of ethyl acetate fraction resulted in the isolation of two constituents designated as compound $\mathbf{1}$, compound $\mathbf{2}$ and petroleum ether extract was obtained as dark green oily mass [10]. The defatted material was extracted further with solvents of increasing polarity. Systematic fractionation of petroleum ether extract resulted in isolation of two constituents designated as compounds 3 and 4 [11]. 
Structural determination of compound 1: Compound 1 was isolated from ethylacetate extract of Kyllinga triceps. It was crystallized in methanol as a yellow crystalline powder having melting point $313-316^{\circ} \mathrm{C}$. It is slightly soluble in water and diethyl ether and soluble in methanol, ethanol and acetone [12]. Chromatography was performed on precoated silica gel $\mathrm{G}$ plates and spots were detected by spraying it with $\mathrm{FeCl}_{3}$ $(2 \%)$ in ethanol. The $\mathrm{R}_{\mathrm{f}}$ value recorded in two solvent systems is given below.

Solvent system $\quad \mathrm{R}_{\mathrm{f}}$ value

Chloroform:ethyl acetate:formic acid (5:4:1) 0.76

n-Butanol:acetic acid:water (4:1:5 upper layer) $\quad 0.82$

The spots appeared blue on spraying it with $\mathrm{FeCl}_{3}$ and in iodine chamber the spots appeared yellowish brown giving a clue that compound is containing phenolic group. The compound gave a positive Shinoda test thus strengthening the assumption that it is a flavonoid compound.

The UV spectrum of the compound 1 showed two major absorption band at 374.8 and 257.5 which gives an idea of its flavonol structure. The bathochromic shift in the UV was observed with sodium acetate at 391.6 and 258.4 (were related of $7 \mathrm{OH}$ group of the flavonoid quercetin) and with aluminium chloride was found to be 435.4 and 270.4 (related to $5 \mathrm{OH}$ group), hypsochromic shift was observed with boric acid at 342.6 and $236.8 \mathrm{~nm}$, confirms the presence of 3,3',4' OH group depicted in Table-1.

\begin{tabular}{lcccc}
\multicolumn{5}{c}{ TABLE-1 } \\
EFFECT OF SHIFT'S REAGENT ON \\
\multicolumn{4}{c}{ THE ABSORPTION MAXIMA OF COMPOUND 1 } \\
\hline Shift's reagent & Band-I & $\begin{array}{l}\text { Shift in } \\
\text { band-I }\end{array}$ & Band-II & $\begin{array}{c}\text { Shift in } \\
\text { band-II }\end{array}$ \\
\hline Quercetin (Q) & 374.8 & & 257.6 & \\
Q + MeONa & 426.6 & 51.8 & 285.8 & 2.2 \\
Q + AlCl & 435.4 & 60.6 & 270.4 & -5.4 \\
Q + HCl & 365.0 & -9.8 & 255.2 & -2.4 \\
Q + Boric acid & 342.6 & -32.0 & 236.8 & -20.8 \\
Q + AcONa & 391.6 & 16.8 & 258.4 & 0.8 \\
Q + NaOH & 332.6 & -42.2 & 233.8 & -23.6 \\
\hline
\end{tabular}

The IR spectrum of the isolated compound $\mathbf{1}(\mathrm{KBr})$, presented various bands mentioned in the Table- 2 .

\begin{tabular}{ll} 
& \multicolumn{1}{c}{ TABLE-2 } \\
& \multicolumn{1}{c}{ IR SPECTRA OF COMPOUND 1 } \\
\hline $\begin{array}{c}\text { Wavenumber } \\
\left(\mathrm{cm}^{-1}\right)\end{array}$ & \multicolumn{1}{c}{ Functional groups and Bonds } \\
\hline 3582 & O-H str. free non bonded \\
3400,3321 & O-H str. vibrational bond in phenol \\
1650 & C=O Aryl ketonic structure \\
$1611,1522,1462$ & C=C aromatic ring streatching (1650-1450) \\
1327 & C-H in-plane bending of aromatic ring \\
$1254,1209,1002$ & C-O str. of phenol, strong band (1260-1000 $\left.\mathrm{cm}^{-1}\right)$ \\
1125 & C-O-C str. of aryl ether (1085-1150) \\
$839,791,721$ & Out of plane C-H bending (900-675) \\
1170 & C-(C=O)-C str. and bend vibrations (1300-1100) \\
\hline
\end{tabular}

The ${ }^{1} \mathrm{H}$ NMR (Chemical shift $\delta$ in ppm, coupling constant $J$ is in $\mathrm{Hz}$ ) spectrum $\left(300 \mathrm{MHz}\right.$, DMSO- $d_{6}$ ) recorded for Cc\#1 depicted following $\delta$ values $6.07(1 \mathrm{H}, \mathrm{d}, J=2.1, \mathrm{C} 6-\mathrm{H}), 6.29$
$(1 \mathrm{H}, \mathrm{d}, J=1.8, \mathrm{C} 8-\mathrm{H}), 7.55\left(1 \mathrm{H}, \mathrm{d}, J=2.1, \mathrm{C} 2{ }^{\prime}-\mathrm{H}\right), 6.75-$ $6.78\left(1 \mathrm{H}, \mathrm{d}, J=8.4, \mathrm{C}^{\prime}-\mathrm{H}\right), 7.40-7.44(1 \mathrm{H}, \mathrm{dd}, J=8.7,2.1$, C6'-H), 9.2 (1H, s, C-4'-OH), 9.1 (1H, s, C3'-OH), 9.4 (1H, s, C3-OH), 12.36 (1H, s, C-5, OH), .10.69 (1H, s, C7-OH).

${ }^{13} \mathrm{C}$ NMR (Chemical shift in ppm) represents 15 carbons. The ${ }^{13} \mathrm{C}$ NMR of compound 1 represents 10 quarternary atoms and 5-CH carbons. The multiplicity and chemical shift of different carbons of compound $\mathbf{1}$ matches with the existing literature for quercetin dihydrate is shown in Table-3.

\begin{tabular}{|c|c|c|c|c|c|}
\hline \multicolumn{6}{|c|}{$\begin{array}{c}\text { TABLE-3 } \\
{ }^{13} \mathrm{C} \text { NMR SPECTRA VALUES OF COMPOUND } 1\end{array}$} \\
\hline Position & Signal & Multiplicity & Position & Signal & Multiplicity \\
\hline 2 & 146.0 & $-\mathrm{C}-$ & 10 & 103.2 & $-\mathrm{C}-$ \\
\hline 3 & 135.5 & $-\mathrm{C}-$ & 1 ' & 122.2 & $-\mathrm{C}-$ \\
\hline 4 & 175.0 & $-\mathrm{C}-$ & 2 ' & 115.3 & $-\mathrm{CH}-$ \\
\hline 5 & 156.0 & $-\mathrm{C}-$ & 3 ' & 144.9 & $-\mathrm{C}-$ \\
\hline 6 & 92.8 & $-\mathrm{CH}-$ & $4^{\prime}$ & 147.4 & $-\mathrm{C}-$ \\
\hline 7 & 164.8 & $-\mathrm{C}-$ & 5, & 114.8 & $-\mathrm{CH}-$ \\
\hline 8 & 93.5 & $-\mathrm{CH}-$ & 6 ' & 120.5 & $-\mathrm{CH}-$ \\
\hline 9 & 161.4 & -C- & - & - & - \\
\hline
\end{tabular}

Mass spectrum of isolated compound $\mathbf{1}$ (molecular weight 302.2) recorded prominent peak at $301\left(\mathrm{M}-\mathrm{H}^{+}\right)$, which on further fragmentation yields prominent fragments weighing 273, 178.8, 150 and 107. Which matches with the existing literature for quercetin dihydrate and thus the compound is quercetin dehydrate (Table-4).

\begin{tabular}{cc} 
TABLE-4 \\
MASS SPECTRUM DATA OF COMPOUND 1 \\
\hline$m / z$ & Name of the fragment \\
\hline 301.1 & $\mathrm{M}-\mathrm{H}^{+}$Base peak \\
273.1 & $\left(\mathrm{M}-\mathrm{H}^{+}-\mathrm{CO}\right)$ \\
178.8 & $\left(301-\mathrm{C}_{7} \mathrm{H}_{6} \mathrm{O}_{2}\right)$ \\
150.0 & $\left(301-\mathrm{C}_{7} \mathrm{H}_{4} \mathrm{O}_{4}\right)$ \\
107.1 & $\mathrm{C}_{7} \mathrm{H}_{6} \mathrm{O}_{2}-\mathrm{CO}-\mathrm{CO}_{2}$ \\
\hline
\end{tabular}<smiles>O=c1c(O)c(-c2ccc(O)c(O)c2)oc2cc(O)cc(O)c12</smiles>

HPLC analysis of the isolated compound 1 was performed by Shimadzu high performance liquid chromatographic system, LC 2010CHT with UV \& PDA detector in combination with Class LC solution software. Kromasil C18, $5 \mu(250 \times 4.6$ $\mathrm{mm}$ ) column was used [13]. Gradient elution was performed using anhydrous sodium dihydrogen orthophosphate buffer and acetonitrile [14]. Flow rate was maintained at $1.5 \mathrm{~mL} / \mathrm{min}$ 
and injection volume was $20.0 \mu \mathrm{L}$ and detection wavelength was $370 \mathrm{~nm}$ [15]. The gradient flow was maintained as given below in the Table-5.

\begin{tabular}{ccc} 
TABLE-5 \\
GRADIENT ELUTION OF COMPOUND 1 WITH \\
\multicolumn{3}{c}{ POTASSIUM DIHYDROGEN ORTHOPHOSPHATE } \\
BUFFER AND ACETONITIRILE \\
\hline Time & Volume of buffer & Volume of acetonitrile \\
\hline 0 & 95 & 5 \\
18 & 55 & 45 \\
25 & 20 & 80 \\
28 & 20 & 80 \\
35 & 55 & 45 \\
40 & 95 & 5 \\
45 & 95 & 5 \\
\hline
\end{tabular}

Retention time of compound $\mathbf{1}$ was observed at 16.568 min. with a peak area of 5546254 which occupies $99.065 \%$. Table-5 and chromatogram proving it a pure entity which matches with the retention time of quercetin.

Structural determination of compound 2: Compound $\mathbf{2}$ was isolated from ethyl acetate extract of Kylling a triceps. It was crystallized in methanol as a yellow powder, soluble in water and methanol (under hot conditions) and insoluble in chloroform, acetone and ether. The melting point was found to be $242-245{ }^{\circ} \mathrm{C}$. Chromatography was performed on precoated silica gel 60 F254 plates and spots were detected by spraying it with $1 \%$ ethanolic aluminium chloride. Yellow fluorescence was observed under UV $365 \mathrm{~nm}$ [16]. The $\mathrm{R}_{\mathrm{f}}$ value recorded in two solvent systems is given below.

$$
\text { Solvent system }
$$

Methanol:water:acetic acid (50:50:6)

$\mathrm{R}_{\mathrm{f}}$ value

Ethyl acetate:water:formic acid (6:1:1)

The glycoside was first eluted with two dimensional TLC with ethyl acetate:water:formic acid (6:1:1) in first direction. The layer was dried at $100{ }^{\circ} \mathrm{C}$ for $15 \mathrm{~min}$, the separation zone was sprayed with $5 \mathrm{M}$ sulphuric acid in water:methanol (1:1) and the plate is kept at $110{ }^{\circ} \mathrm{C}$ for $40 \mathrm{~min}$ to hydrolyze the glycoside. After cooling elution in second direction was done with ethyl acetate:2-butanol:water (60:25:5). Plates were dried at $80{ }^{\circ} \mathrm{C}$ for $15 \mathrm{~min}$ and then sprayed with saturated solution of ethylenediammoniumsulphate in acetone:water (1:1). The sugar under these conditions give rise to fluorescent blue spots which may be observed under UV (365 nm) [17].

The compound in methanol gave two significant absorption band at $357.6 \mathrm{~nm}$ (band-I) and 257.6 (band-II) which gives an idea of flavonol structure. Significant bathochromic shift in the absorption maxima is observed with sodium methoxide, aluminium chloride and and sodium hydroxide hypsochromic shift is observed only with $\mathrm{HCl}$ [18]. The shift in the absorption maxima was observed on treating it with shift reagents which is given in Table- 6 .

The IR spectra of the isolated compound was performed with $\mathrm{KBr}$ disc method and various bands observed are mentioned in the Table-7.

${ }^{1} \mathrm{H}$ NMR (chemical shift $\delta$ in ppm, coupling constant $J$ is in $\mathrm{Hz}$ ) spectrum $\left(300 \mathrm{MHz}, \mathrm{DMSO}-d_{6}\right)$ recorded as 6.06.08 (1H, d, $J=1.8, \mathrm{C} 6-\mathrm{H}), 6.26-6.27$ (1H, d, $J=2.1, \mathrm{C} 8-\mathrm{H})$,

\begin{tabular}{lcccc}
\multicolumn{5}{c}{ TABLE-6 } \\
\multicolumn{5}{c}{ EFFECT OF SHIFT'S REAGENT ON THE } \\
ABSORPTION MAXIMA OF COMPOUND 2 \\
\hline Shift's reagent & $\begin{array}{c}\text { Band-I } \\
(\mathrm{nm})\end{array}$ & $\begin{array}{c}\text { Shift in } \\
\text { band-I } \\
(\mathrm{nm})\end{array}$ & $\begin{array}{c}\text { Band-II } \\
(\mathrm{nm})\end{array}$ & $\begin{array}{c}\text { Shift in } \\
\text { band-II } \\
(\mathrm{nm})\end{array}$ \\
\hline Rutin (R) & 357.6 & - & 257.6 & - \\
$\mathrm{R}+\mathrm{MeONa}$ & 410.6 & 53.0 & 273.4 & 15.8 \\
$\mathrm{R}+\mathrm{AlCl}_{3}$ & 428.0 & 70.4 & 275.0 & 17.4 \\
$\mathrm{R}+\mathrm{HCl}$ & 359.6 & 2.0 & 257.2 & -0.4 \\
$\mathrm{R}+\mathrm{Boric}$ acid & 363.6 & 6.0 & 258.0 & 0.4 \\
$\mathrm{R}+\mathrm{AcONa}$ & 385.4 & 1.8 & 274.2 & 16.6 \\
$\mathrm{R}+\mathrm{NaOH}$ & 411.2 & 53.6 & 274.4 & 16.8 \\
\hline
\end{tabular}

TABLE-7

IR SPECTRA OF COMPOUND 2 isolated from Kyllinga triceps

\begin{tabular}{ll}
\hline \multicolumn{1}{c}{ Wavenumber $\left(\mathrm{cm}^{-1}\right)$} & \multicolumn{1}{c}{ Functional groups and bonds } \\
\hline 3592 & $\begin{array}{l}\text { O-H str. (non-bonded, free) vibrational band } \\
\text { (3700-3584) }\end{array}$ \\
3408,3321 & $\begin{array}{l}\text { O-H str. bonded (3550-3200) } \\
\text { C=O aryl ketonic structure (1685-1666), } \\
\text { frequency reduced due to conjugation and } \\
\text { intramolecular H bonding }\end{array}$ \\
1663 & C=C aromatic ring stretching (1650-1450) \\
$1611,1561,1521$ & C-H in-plane bending of aromatic ring \\
1321 & C-O str. of phenol, strong band (1260-1000 \\
1199,1013 & cm $\left.{ }^{-1}\right)$ \\
1150 & C-O-C str. of aryl ether (1085-1150) \\
$865,823,723,685$ & Out of plane C-H bending (900-675) \\
1264 & C-(C=O)-C str. and bend vibrations (1300- \\
& 1100) \\
\hline
\end{tabular}

7.41-7.43 (1H, d, $\left.J=1.8, \mathrm{C} 2{ }^{\prime}-\mathrm{H}\right), 6.71-6.73(1 \mathrm{H}, \mathrm{d}, J=8.4$, C5'-H), 7.41-7.44 (1H, dd, $\left.J=8.8,2.2, \mathrm{C}^{\prime}{ }^{\prime}-\mathrm{H}\right), 9.56(1 \mathrm{H}, \mathrm{s}$, 4'-OH), 9.06 (1H, s, 3'-OH)12.47 (1H, s, C-5, OH), 10.74 $(1 \mathrm{H}, \mathrm{s}, \mathrm{C}-7 \mathrm{OH}), 5.23(1 \mathrm{H}, \mathrm{d}, J=3.9, \mathrm{H} 1-\mathrm{G}), 5.12(1 \mathrm{H}, \mathrm{d}, J=$ 1.6, H1-R), $0.8\left(3 \mathrm{H}, J=5.8, \mathrm{CH}_{3}-\mathrm{R}\right)$.

${ }^{13} \mathrm{C}$ NMR (chemical shift in ppm) displayed the signals for various carbons of the compound 2 (DMSO- $d_{6}$ ) where there are One $\mathrm{CH}_{3}$, one $\mathrm{CH}_{2}, 14 \mathrm{CH}$ and 11 quarternary carbons, The assignment of chemical shift was facilitated on comparison with ${ }^{13} \mathrm{C}$ NMR data of rutin available in the literature. The chemical shift of various carbons is given in Table- 8 .

\begin{tabular}{|c|c|c|c|c|c|}
\hline \multicolumn{6}{|c|}{$\begin{array}{c}\text { TABLE-8 } \\
{ }^{13} \mathrm{C} \text { NMR SPECTRAL DATA OF COMPOUND } 2 \\
\text { ISOLATED FROM Kyllinga triceps }\end{array}$} \\
\hline $\begin{array}{l}\text { Chemical } \\
\text { shift }(\delta \\
\text { scale })\end{array}$ & $\begin{array}{c}\text { Carbon } \\
\text { No. }\end{array}$ & $\begin{array}{l}\text { Multi- } \\
\text { plicity }\end{array}$ & $\begin{array}{l}\text { Chemical } \\
\text { shift } \\
(\delta \text { scale })\end{array}$ & $\begin{array}{c}\text { Carbon } \\
\text { No. }\end{array}$ & $\begin{array}{l}\text { Multi- } \\
\text { plicity }\end{array}$ \\
\hline 157.06 & $\mathrm{C}-2$ & $-\mathrm{C}-$ & 121.60 & C-6' & $-\mathrm{CH}-$ \\
\hline 133.70 & C-3 & $-\mathrm{C}-$ & 101.60 & C1-G & -C- \\
\hline 177.80 & C-4 & $-\mathrm{C}-$ & 74.50 & C2-G & $-\mathrm{CH}-$ \\
\hline 156.80 & C-5 & $-\mathrm{C}-$ & 76.90 & C3-G & $-\mathrm{CH}-$ \\
\hline 99.10 & C-6 & -CH- & 72.30 & C4-G & $-\mathrm{CH}-$ \\
\hline 164.50 & C-7 & $-\mathrm{C}-$ & 76.30 & $\mathrm{C} 5-\mathrm{G}$ & $-\mathrm{CH}-$ \\
\hline 94.03 & C-8 & $-\mathrm{CH}-$ & 67.40 & C6-G & $-\mathrm{CH}_{2}-$ \\
\hline 161.60 & C-9 & -C- & 101.60 & C1-R & $-\mathrm{CH}-$ \\
\hline 104.40 & C-10 & $-\mathrm{C}-$ & 70.80 & C2-R & -CH- \\
\hline 122.04 & C-1' & $-\mathrm{C}-$ & 71.03 & C3-R & $-\mathrm{CH}-$ \\
\hline 115.60 & C-2' & -CH- & 70.48 & C4-R & -CH- \\
\hline 145.20 & C-3' & $-\mathrm{C}-$ & 68.69 & C5-R & $-\mathrm{CH}-$ \\
\hline 148.70 & C-4' & $-\mathrm{C}-$ & 18.18 & C6-R & $-\mathrm{CH}_{3}$ \\
\hline 116.70 & C-5' & -CH- & - & - & - \\
\hline
\end{tabular}


The mass spectrum of the compound 2 on fragmentation gave the following fragments shown in Table-9.

\section{TABLE-9}

MASS FRAGMENTATION DATA OF COMPOUND 2

\begin{tabular}{cc}
\hline$m / z$ & Name of the fragment \\
\hline 609.15 & $\mathrm{M}-\mathrm{H}^{+}$Base peak \\
596.00 & $\mathrm{M}+\mathrm{H}^{+}-\left(\mathrm{CH}_{3}\right)$ \\
463.00 & $\mathrm{M}^{+}-\left(\mathrm{C}_{6} \mathrm{H}_{10} \mathrm{O}_{4}\right)$ \\
325.00 & $\mathrm{M}^{+}-\left(\mathrm{C}_{15} \mathrm{H}_{9} \mathrm{O}_{6}\right)$ \\
300.00 & $\mathrm{M}^{+}-\left(\mathrm{C}_{12} \mathrm{H}_{21} \mathrm{O}_{9}\right)$ glycone part $)$ \\
\hline
\end{tabular}

$\mathrm{M}-\mathrm{H}^{+}$and $\mathrm{M}+\mathrm{H}^{+}$are the most abundant and characteristic peaks in flavonols, compound $\mathbf{2}$ seems to be rutin as the mass fragmentation pattern and presence of base peak at 609.15 $\left(\mathrm{M}-\mathrm{H}^{+}\right)$on matching with the existing literature increases the probability of the compound to be rutin.

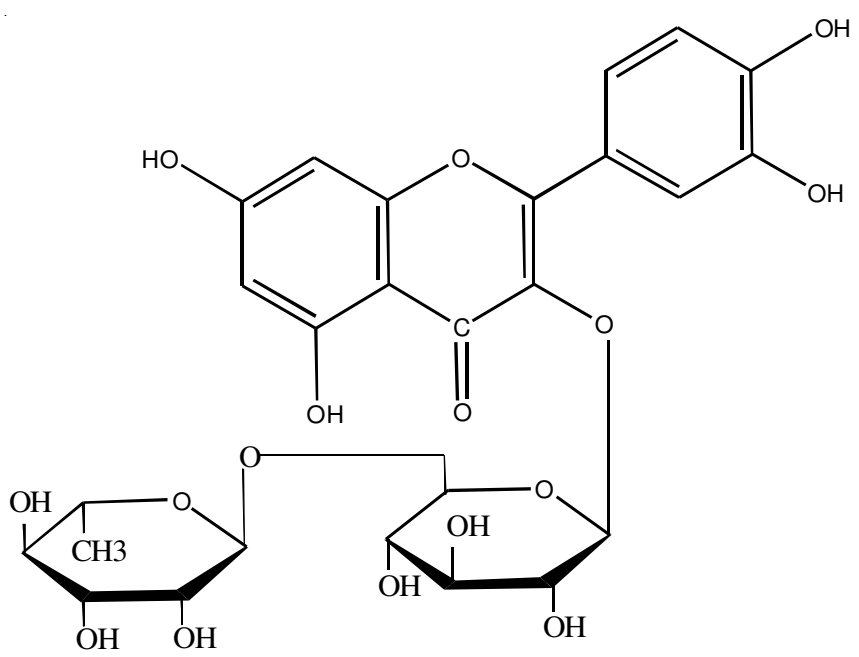

Structure of rutin

The identity of the isolated compound 2 , which may be rutin was further confirmed by HPLC using Shimadzu high performance liquid chromatographic system LC 2010CHT with UV detector. Kromasil C18 column was used. Gradient elution was conducted using potassium dihydrogen orthophosphate buffer (A) and acetonitrile (B). The buffer (A) was prepared by taking $0.140 \mathrm{~g}$ of anhydrous potassium dihydrogen orthophosphate $\left(\mathrm{KH}_{2} \mathrm{PO}_{4}\right)$ dissolving it in $900 \mathrm{~mL}$ of HPLC grade water and adding $0.5 \mathrm{~mL}$ of orthophosphoric acid and making volume up to $1000 \mathrm{~mL}$ with water. The solution was filtered through $0.45 \mu$ membrane filter and degassed in a sonicator for $3 \mathrm{~min}$. HPLC grade acetonitrile was used. Flow rate was kept at $1.6 \mathrm{~mL} / \mathrm{min}$ and detection wavelength was maintained at $258 \mathrm{~nm}$ and injection volume was $20 \mu \mathrm{L}$. About $5 \mathrm{mg}$ of the sample was weighed to a in a $25 \mathrm{~mL}$ volumetric flask. About $10 \mathrm{~mL}$ of methanol was added and sonicated cooled and made up to $25 \mathrm{~mL}$ with methanol. The gradient flow was maintained as given in Table- 10 .

The retention time obtained was 3.257 min with a peak area of 4113012 and peak area \% of 98.347 .

Structural determination of compound 3: Compound 3 was isolated from petroleum ether extract of the entire plant of Kyllinga triceps. Petroleum ether extract is first treated with alcoholic $\mathrm{KOH}$ to saponify the fats and washed again with

\begin{tabular}{ccc}
\multicolumn{3}{c}{ TABLE-10 } \\
GRADIENT ELUTION OF RUTIN WITH \\
POTASSIUM DIHYDROGEN ORTHOPHOSPHATE \\
BUFFER AND ACETONITIRILE \\
\hline Time (min) & Volume of buffer & Volume of acetonitrile \\
\hline 0 & 80 & 20 \\
5 & 75 & 25 \\
8 & 70 & 30 \\
10 & 70 & 30 \\
12 & 80 & 20 \\
15 & 80 & 20 \\
15 & Stop & \\
\hline
\end{tabular}

petroleum ether to purify the remaining extract. This extract is further subjected to column chromatography using gradient elution with toluene and methanol, homogeneity was established by TLC studies over precoated silica gel G plates and the spots were developed by either exposing the plates to iodine vapours or spraying them with $5 \%$ ethanolic sulphuric acid followed by heating the plates at $110^{\circ} \mathrm{C}$ for $10 \mathrm{~min}$. The $\mathrm{R}_{\mathrm{f}}$ values recorded in two different solvent systems are given below.

\section{Solvent system \\ $\mathrm{R}_{\mathrm{f}}$ value \\ Benzene:chloroform $(2: 1)$ \\ 0.64 \\ Toluene:chloroform:methanol (1:1:0.1) \\ 0.57}

Compound 3 was found to be soluble in organic solvents like petroleum ether, benzene, dichloromethane, chloroform and methanol but insoluble in water. The melting point was found to be $160-166{ }^{\circ} \mathrm{C}$ [19].

The IR spectrum of the compound $\mathbf{3}$ gave the following peaks mentioned in Table-11.

\begin{tabular}{cl} 
& \multicolumn{1}{c}{ TABLE-11 } \\
& \multicolumn{1}{c}{ IR SPECTRA OF COMPOUND 3 } \\
ISOALTED FROM Kyllinga triceps
\end{tabular}

It is observed that with acetic anhydride and triethylamine at room temperature isolated compound afforded an acetate derivative, m.p., 143-145 ${ }^{\circ} \mathrm{C}$. Thus compound 3 appeared to be stigmasterol and this assumption was confirmed by recording and analyzing ${ }^{1} \mathrm{H} \mathrm{NMR},{ }^{13} \mathrm{C} \mathrm{NMR}$ and mass spectrum of compound 3 [19].

The ${ }^{1} \mathrm{H}$ NMR (chemical shift $\delta$ in ppm, coupling constant $J$ is in $\mathrm{Hz}$ ) spectrum $\left(300 \mathrm{MHz}, \mathrm{CdCl}_{3}\right)$ recorded as $1.12(3 \mathrm{H}$, $\mathrm{t}, J=7.05, \mathrm{C}-29), 0.83$ (3H, d $J=5.1, \mathrm{C}-27), 0.78$, (3H, d $J=$ 6.3, C-26), 0.96 (3H, d, $J=6.3, \mathrm{C}-21), 2.21(1 \mathrm{H}, \mathrm{m}, \mathrm{C}-20)$, $0.62(3 \mathrm{H}, \mathrm{s}, \mathrm{C}-18) 1.18(3 \mathrm{H}, \mathrm{s}, \mathrm{C}-19), 5.12(1 \mathrm{H}, \mathrm{dd}, J=8.4$, $8.4, \mathrm{C}-23), 4.98$ (1H, dd, $J=8.4,8.4, \mathrm{C}-22), 5.28(1 \mathrm{H}, \mathrm{t}, J=$ 7.5, C-6), $3.45(1 \mathrm{H}, \mathrm{m}, \mathrm{C}-3)$, for methine and methylene protons of steroidal ring and side chain.

${ }^{13} \mathrm{C}$ NMR (300 MHz, $\mathrm{CDCl}_{3}$ ) apart from other signals showed the presence of one oxy carbon $\left(\delta_{c}, 72.1\right)$ four olefinic 
carbons $\left(\delta_{\mathrm{C}}, 129.2,138.3,121.69,140.76\right)$ and six methyl carbon $\left(\delta_{\mathrm{C}}, 12.24,18.9,19.39,19.39,12.05,21.2\right)$ the multiplicity and chemical shift of different carbons of compound $\mathbf{3}$ are shown in Table-12.

\begin{tabular}{cccccc}
\multicolumn{7}{c}{ TABLE-12 } \\
\multicolumn{7}{c}{$\begin{array}{l}{ }^{13} \mathrm{C} \text { NMR SPECTRAL DATA OF COMPOUND 3 } \\
\text { Chemical } \\
\text { shift }(\delta \\
\text { scale) }\end{array}$} & $\begin{array}{c}\text { Carbon } \\
\text { No. }\end{array}$ & $\begin{array}{c}\text { Multi- } \\
\text { plicity }\end{array}$ & $\begin{array}{c}\text { Chemical } \\
\text { shift }(\delta \\
\text { scale })\end{array}$ & $\begin{array}{c}\text { Carbon } \\
\text { No. }\end{array}$ & $\begin{array}{c}\text { Multi- } \\
\text { plicity }\end{array}$ \\
\hline 12.05 & 18 & $\mathrm{CH}_{3}$ & 37.2 & 1 & $\mathrm{CH}_{2}$ \\
12.24 & 29 & $\mathrm{CH}_{3}$ & 39.2 & 12 & $\mathrm{CH}_{2}$ \\
18.98 & 27 & $\mathrm{CH}_{3}$ & 40.48 & 20 & $-\mathrm{CH}$ \\
19.39 & 19 & $\mathrm{CH}_{3}$ & 42.32 & 13 & $-\mathrm{C}-$ \\
21.07 & 11 & $\mathrm{CH}_{2}$ & 42.32 & 4 & $-\mathrm{CH}$ \\
21.07 & 21 & $\mathrm{CH}_{3}$ & 50.18 & 9 & $-\mathrm{CH}$ \\
21.2 & 26 & $\mathrm{CH}_{2}$ & 51.24 & 24 & $-\mathrm{CH}$ \\
24.3 & 15 & $\mathrm{CH}_{2}$ & 55.97 & 17 & $-\mathrm{CH}$ \\
25.4 & 28 & $\mathrm{CH}_{2}$ & 56.8 & 14 & $\mathrm{CH}$ \\
28.9 & 16 & $\mathrm{CH}_{2}$ & 71.8 & 3 & $\mathrm{CH}$ \\
31.6 & 2 & $\mathrm{CH}_{2}$ & 121.69 & 6 & $\mathrm{CH}$ \\
31.6 & 7 & $\mathrm{CH}_{2}$ & 129.29 & 23 & $\mathrm{CH}$ \\
31.9 & 8 & $\mathrm{CH}_{2}$ & 138.30 & 22 & $\mathrm{CH}$ \\
31.9 & 25 & $\mathrm{CH}_{3}$ & 140.76 & 5 & $-\mathrm{C}-$ \\
36.5 & 10 & $-\mathrm{C}_{-}$ & - & - & - \\
\hline
\end{tabular}

Mass spectroscopic fragmentation of the isolated compound 3 yielded $\mathrm{M}^{+}$at $m / z 412$, with other prominent fractions at $m / z$ $395\left(\mathrm{C}_{29} \mathrm{H}_{47}\right), 255\left(\mathrm{C}_{19} \mathrm{H}_{29} \mathrm{O}\right), 311\left(\mathrm{C}_{23} \mathrm{H}_{35}\right), 297\left(\mathrm{C}_{22} \mathrm{H}_{33} \mathrm{O}\right)$ and $233\left(\mathrm{C}_{17} \mathrm{H}_{26} \mathrm{O}\right)$. Fragmentation pattern is shown in Table-13.

TABLE-13

MASS FRAGMENTATION DATA OF ISOLATED COMPOUND 3

\begin{tabular}{cc}
\hline$m / z$ & Name of the fragment \\
\hline 412 & $\mathbf{M}^{+}$molecular ion peak \\
395 & $\left(\mathbf{M}^{+}-\mathrm{OH}\right)$ \\
311 & $\left(\mathbf{M}^{+}-\mathrm{OH}-\mathrm{C}_{6} \mathrm{H}_{13}\right)$ \\
297 & $\left(\mathbf{M}^{+}-\mathrm{H}\right)-\mathrm{C}_{7} \mathrm{H}_{14}$ \\
255 & $\mathbf{M}^{+}-\left(\mathrm{C}_{10} \mathrm{H}_{19}\right)$ \\
233 & $\left(\mathbf{M}^{+}-\mathrm{H}\right)-\mathrm{C}_{7} \mathrm{H}_{14}-\mathrm{C}_{5} \mathrm{H}_{7}$ \\
\hline
\end{tabular}<smiles>CCC(C=CC(C)C(C)C)C1CCC2C=C3CC(O)CCC3CCC21</smiles>

The identity of the isolated compound $\mathbf{3}$ which may be stigmasterol was further confirmed by HPLC using Shimadzu high performance liquid chromatographic system LC 2010CHT with UV detector, Kromasil C18 column was used, gradient elution was conducted using toluene (A) and methanol (B). Flow rate was maintained at $2 \mathrm{~mL} / \mathrm{min}$ and detection wavelength was maintained at $205 \mathrm{~nm}$ and injection volume was $20 \mu \mathrm{L}$. About $10 \mathrm{mg}$ of the sample was weighed to a $10 \mathrm{~mL}$ volumetric flask. $5 \mathrm{~mL}$ of methanol was added and sonicated cooled and volume was made up to $10 \mathrm{~mL}$. Retention time of Compound $\mathbf{3}$ was found to be 6.089 min with peak area of 2581295 and peak \% of 99.6 [20].

Structural determination of compound 4: Compound 4, was isolated from petroleum ether extract of Kyllinga triceps. Petroleum ether extract was first treated with alcoholic potassium hydroxide to saponify the fatty acids which removed the fatty acids present in the extract. After removal of fatty acids, petroleum ether extract is subjected to gradient elution column chromatography using, toluene and methanol (95:5), 68 fractions were obtained. The fractions were concentrated and purified and subjected to identification through TLC by using various solvents. The spots of isolated compound was detected by exposing the plates to iodine vapours or observing the plates in UV light and also by spraying the plates with (5\%) sulphuric acid reagent in methanol followed by heating the plates at $110{ }^{\circ} \mathrm{C}$ for $10 \mathrm{~min}$. The $\mathrm{R}_{\mathrm{f}}$ value recorded in two different solvent system are given below.

\begin{tabular}{ll}
\multicolumn{1}{c}{ Solvent system } & $\mathrm{R}_{\mathrm{f}}$ value \\
Chloroform: ethanol $(9.6: 0.4)$ & 0.55 \\
Chloroform: ethyl acetate $(8.5: 1.5)$ & 0.63
\end{tabular}

Compound 4 was found to be soluble in organic solvents like petroleum ether, benzene, dichloromethane, chloroform and methanol but insoluble in water. The melting point was found to be $172-174{ }^{\circ} \mathrm{C}$ [21].

The IR spectrum of the compound $\mathbf{4}$ gave the following peaks mentioned in Table-14.

\begin{tabular}{|c|c|}
\hline & $\begin{array}{c}\text { TABLE-14 } \\
\text { IR SPECTRA OF COMPOUND } 4\end{array}$ \\
\hline $\begin{array}{l}\text { Wavenumber } \\
\left(\mathrm{cm}^{-1}\right)\end{array}$ & Functional groups and bonds \\
\hline 3476 & O-H str. vibrational band of bonded $-\mathrm{OH}$ \\
\hline 2962 & $\mathrm{CH}$ unsymmetrical str. of geminal dimethyl group \\
\hline 2831 & $\mathrm{CH}$ str. of steroidal ring and tertiary $\mathrm{CH}$ group \\
\hline 1653 & $\begin{array}{l}\mathrm{C}=\mathrm{C} \text { str. of unconjugated alkene showing weak } \\
\text { absorption band }\end{array}$ \\
\hline 1453 & $\begin{array}{l}-\mathrm{CH} \text { bending vibration due to }-\mathrm{CH}_{2} \text { scissoring } \\
\text { vibration }\end{array}$ \\
\hline 1379 & $\mathrm{O}-\mathrm{H}$ bending vibration \\
\hline 1077 & $-\mathrm{C}-\mathrm{O}$ stretching $\left(1260-1000 \mathrm{~cm}^{-1}\right)$ \\
\hline 953,837 & $\begin{array}{l}\mathrm{C}-\mathrm{H} \text { in plane bending of cyclo alkenes }(1000-650 \\
\left.\mathrm{cm}^{-1}\right)\end{array}$ \\
\hline
\end{tabular}

It is observed that with acetic anhydride and triethylamine at room temperature isolated compound afforded an acetate derivative. Thus compound $\mathbf{4}$ appeared to be a steroidal compound and this assumption was confirmed by recording and analyzing ${ }^{1} \mathrm{H} \mathrm{NMR},{ }^{13} \mathrm{C}$ NMR and mass spectrum of compound 4.

The ${ }^{1} \mathrm{H}$ NMR (chemical shift $\delta$ in ppm, coupling constant $J$ is in $\mathrm{Hz}$ ) spectrum $\left(300 \mathrm{MHz}, \mathrm{CdCl}_{3}\right.$ recorded as $0.80(3 \mathrm{H}, \mathrm{t}$, $J=7.05, \mathrm{C}-29), 0.84$ (3H, d $J=6.3, \mathrm{C}-27), 0.61$ (3H, d $J=$ 9.3, C-26), 1.10 (3H, d $J=9.3, \mathrm{C}-21), 2.24(1 \mathrm{H}, \mathrm{m}, \mathrm{C}-20)$, 1.18 (3H, s, C-19), 0.61 (3H, s, C-18), 5.27 (1H, t $J=5.4$, C$6), 3.41(1 \mathrm{H}, \mathrm{m}, \mathrm{C}-3)$, for methine and methylene protons of steroidal ring and side chain. 
The ${ }^{13} \mathrm{C}$ NMR of compound 4 was recorded in $\mathrm{CDCl}_{3}$ and the chemical shift of different carbon is mentioned in Table- 15 .

\begin{tabular}{cccccc}
\multicolumn{7}{c}{ TABLE-15 } \\
\multicolumn{7}{c}{${ }^{13} \mathrm{C}$ NMR SPECTRAL DATA OF COMPOUND 4 } \\
\hline $\begin{array}{c}\text { Chemical } \\
\text { shift }(\delta \\
\text { scale })\end{array}$ & $\begin{array}{c}\text { Carbon } \\
\text { No. }\end{array}$ & $\begin{array}{c}\text { Multi- } \\
\text { plicity }\end{array}$ & $\begin{array}{c}\text { Chemical } \\
\text { shift }(\delta \\
\text { scale })\end{array}$ & $\begin{array}{c}\text { Carbon } \\
\text { No. }\end{array}$ & $\begin{array}{c}\text { Multi- } \\
\text { plicity }\end{array}$ \\
\hline 11.84 & 18 & $\mathrm{CH}_{3}$ & 33.99 & 22 & $\mathrm{CH}$ \\
11.97 & 29 & $\mathrm{CH}_{3}$ & 36.13 & 20 & $\mathrm{CH}_{2}$ \\
18.77 & 21 & $\mathrm{CH}_{3}$ & 36.52 & 10 & $\mathrm{CH}_{2}$ \\
19.04 & 27 & $\mathrm{CH}_{3}$ & 37.28 & 1 & $-\mathrm{CH}$ \\
19.37 & 19 & $\mathrm{CH}_{2}$ & 39.81 & 12 & $-\mathrm{C}-$ \\
19.78 & 26 & $\mathrm{CH}_{3}$ & 42.32 & 4 & $-\mathrm{CH}$ \\
21.09 & 11 & $\mathrm{CH}_{2}$ & 42.30 & 13 & $-\mathrm{C}-$ \\
23.11 & 28 & $\mathrm{CH}_{2}$ & 45.90 & 24 & $-\mathrm{CH}$ \\
24.29 & 15 & $\mathrm{CH}_{2}$ & 50.19 & 9 & $-\mathrm{CH}$ \\
26.19 & 23 & $\mathrm{CH}_{2}$ & 56.11 & 17 & $-\mathrm{CH}$ \\
28.22 & 16 & $\mathrm{CH}_{2}$ & 56.80 & 14 & $\mathrm{CH}$ \\
29.23 & 25 & $\mathrm{CH}_{2}$ & 71.80 & 3 & $\mathrm{CH}$ \\
31.69 & 2 & $\mathrm{CH}^{2}$ & 121.68 & 6 & $\mathrm{CH}$ \\
31.93 & 7 & $\mathrm{CH}_{3}$ & 140.78 & 5 & $\mathrm{CH}$ \\
31.93 & 8 & $-\mathrm{CH}^{2}$ & - & - & - \\
\hline
\end{tabular}

Mass spectroscopic fragmentation of the isolated compound 4 yielded $\mathrm{M}^{+}$at $m / z 412$, with other prominent fractions at $m / z, 395\left(\mathrm{C}_{29} \mathrm{H}_{47}\right), 255\left(\mathrm{C}_{19} \mathrm{H}_{29} \mathrm{O}\right), 311\left(\mathrm{C}_{23} \mathrm{H}_{35}\right), 297\left(\mathrm{C}_{22} \mathrm{H}_{33} \mathrm{O}\right)$, $233\left(\mathrm{C}_{17} \mathrm{H}_{26} \mathrm{O}\right)$. Fragmentation pattern is shown in Table-16.

TABLE-16

MASS FRAGMENTATION DATA OF ISOLATED COMPOUND 4

\begin{tabular}{cc}
\hline$m / z$ & Name of the fragment \\
\hline 414 & $\mathrm{M}^{+}$molecular ion peak merged $/ \mathrm{C}_{29} \mathrm{H}_{50} \mathrm{O}$ \\
397 & $\left(\mathrm{M}^{+}-\mathrm{OH}\right) / \mathrm{C}_{29} \mathrm{H}_{49}$ base peak \\
383 & $\left(\mathrm{M}^{+}-\mathrm{OH}-\mathrm{CH}_{3}\right) / \mathrm{C}_{28} \mathrm{H}_{47}$ \\
257 & $\left(\mathrm{M}^{+}-\mathrm{OH}\right)-\mathrm{C}_{10} \mathrm{H}_{21} / \mathrm{C}_{19} \mathrm{H}_{29}$ \\
\hline
\end{tabular}

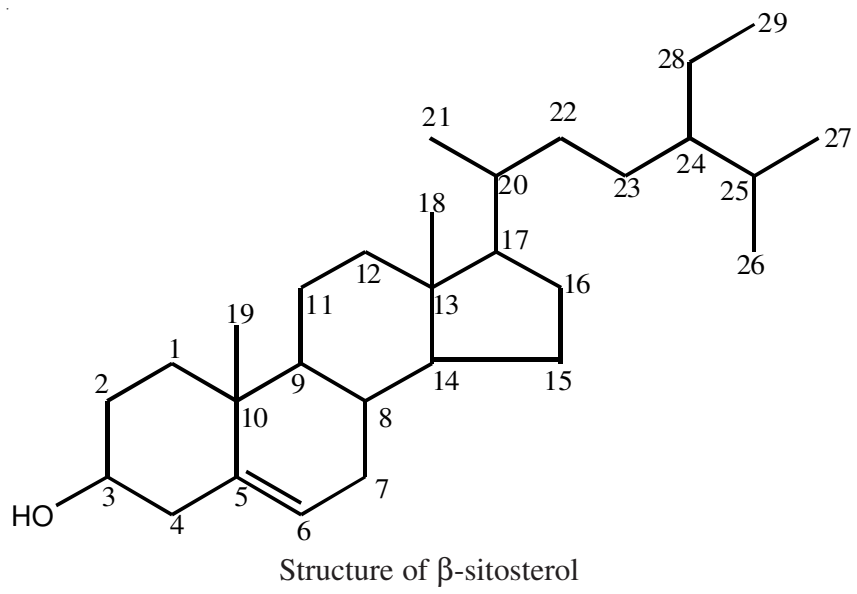

The identity of the isolated compound $\mathbf{4}$ which was found to be $\beta$-sitosterol was further confirmed by HPLC using Shimadzu high performance liquid chromatographic system with LC 8A pump and UV detector and polymer ELS detector in combination with class LC10A software. Kromasil RP C-8, $250 \times$ $4.6 \mathrm{~mm} \times 5 \mu$ column was used. Isocratic elution was conducted using methanol:water (99:1). ELSD (evaporative light scattering detection) conditions includes nebulized temperature of 75 ${ }^{\circ} \mathrm{C}$, evaporation temperature $90^{\circ} \mathrm{C}$ and gas flow was maintained at $1.0 \mathrm{SLM}$. For sample preparation $10 \mathrm{mg}$ of sample was dissolved in $5 \mathrm{~mL}$ of acetone, sonicated, slightly warmed at 40 ${ }^{\circ} \mathrm{C}$ for $0.5 \mathrm{~min}$ and made up to $10 \mathrm{~mL}$ and injected immediately.

Retention time of compound $\mathbf{4}$ was found to be 3.025 min with peak area of 946261 with peak \% of 99.62 .

\section{RESULTS AND DISCUSSION}

The four compounds were isolated (two from ethyl acetate fraction and two from petroleum ether extract) of Kyllinga triceps. Both the compounds isolated from ethyl acetate fraction gave positive Shinoda test for flavonoids and in TLC also. The compound gave blue spots on spraying it with ferric chloride thus confirming the phenolic nature of both the compound. Compound 1 was crystallized in methanol as a yellow crystalline powder having melting point $313-316{ }^{\circ} \mathrm{C}$. It is slightly soluble in water and diethyl ether and soluble in methanol, ethanol and acetone. Compound $\mathbf{2}$ was crystallized in methanol as a yellow powder, soluble in water and methanol (under hot conditions) and insoluble in chloroform, acetone and ether. It was found to have melting point $242-245^{\circ} \mathrm{C}$.

Both the compounds when treated with shift reagent depicted bathochromic and hypsochromic shift which is the characteristic feature of flavonol glycosides.

IR spectroscopic analysis of compound $\mathbf{1}$ showed absorption band at $3582 \mathrm{~cm}^{1}$ that is characteristic of free $\mathrm{OH}$ stretching, absorption bands at $3400,3321 \mathrm{~cm}^{1}$ are due to bonded $\mathrm{OH}$ group, absorption band at $1650 \mathrm{~cm}^{-1}$ is due to aryl ketone and the decrease in the absorption frequency is due to intramolecular hydrogen bonding between $\mathrm{OH}$ group of 3C, $\mathrm{C}=\mathrm{O}$ group of $4 \mathrm{C}$ and $\mathrm{OH}$ group of 5 carbon. Absorption at 1611 , 1522,1462 is due to $\mathrm{C}=\mathrm{C}$ aromatic stretching. Absorption at $839,791,721 \mathrm{~cm}^{-1}$ is quiet prominent due to out of plane (oops) $\mathrm{C}-\mathrm{H}$ bending in aromatic ring.

Compound 2 gave various absorption bands which are $3592 \mathrm{~cm}^{1}$ (free $\mathrm{OH}$ groups), 3408, $3321 \mathrm{~cm}^{1}$ (due to bonded OH groups), $1663 \mathrm{~cm}^{1}$ (aryl ketonic group representing intra molecular hydrogen bond), 1611, 1561, $1521 \mathrm{~cm}^{1}$ (C=C aromatic ring stretching), $865,823,723,685, \mathrm{~cm}^{1}$ due to out of plane (oops) $\mathrm{C}-\mathrm{H}$ bending in aromatic ring. The absorption bands were found in the same range so possibilities are that in both the compounds some of the bonds and functional groups are common. For further confirmation both the compounds were subjected to ${ }^{1} \mathrm{H}$ NMR, ${ }^{13} \mathrm{C}$ NMR and Mass spectroscopic analysis.

The ${ }^{1} \mathrm{H}$ NMR and data of compound $\mathbf{1}$ resembles with that of quercetin with singlets at $\delta$ value 9.2, 9.1, 9.4, 12.36, 10.69 for OH at C4', C3', C3, C5 and C7 respectively. Doublet were observed at $\delta$ value $6.07,6.29,7.55,6.78$ for protons at C6, C8, C2' and C5' and double doublet at 7.40-7.44 for, C6 ' $\mathrm{H}$, which matches with the existing literature for quercetin.

The ${ }^{1} \mathrm{H}$ NMR and data of compound 2 resembles with that of quercetin but some extra peaks were observed at at $\delta$ value 5.23 (for $\mathrm{H} 1-\mathrm{G}$, glucose moiety), 5.12 (for H1-R, rhamnose moiety) and 0.8 for $\mathrm{CH}_{3}-\mathrm{R}$, which confirms that compound $\mathbf{2}$ is a glycoside of quercetin with glucose and rhamnose moiety attached with it. Other peaks of aglycone moiety resembling quercetin were observed as singlets at $\delta$ value 9.56, 9.06, 12.47, 10.74 for $\mathrm{OH}$ at C4', C3', C5 and C7 
respectively. Doublet were observed at $\delta$ value $6.08,6.27,7.44$ and 6.73 for protons at $\mathrm{C} 6, \mathrm{C} 8, \mathrm{C} 2$ ', $\mathrm{C} 5$ '. and double doublet was also observed at 7.41-7.44 for, C-6' $\mathrm{H}$, some more peak doublet which matches with the existing literature for rutin.

The value of ${ }^{13} \mathrm{C}$ NMR of compound $\mathbf{1}$ and $\mathbf{2}$ resembles closely with each other and with that of existing literature. The $\delta$ value of compound 2 , differs from that of compound $\mathbf{1}$ due the presence of carbons in the glucose and rhamnose moiety (Tables 3 and 8 ).

The retention time of isolated compound $\mathbf{1}$ was found to be $16.568 \mathrm{~min}$ and that of compound 2 was $3.257 \mathrm{~min}$.

Mass spectrum of isolated compound $\mathbf{1}$ (molecular weight 302.2) recorded prominent peak at $301\left(\mathrm{M}-\mathrm{H}^{+}\right)$, which on further fragmentation yields prominent fragments weighing $273,178.8,150$ and 107. Which matches with the existing literature for quercetin dihydrate and thus the compound is quercetin dihydrate. Mass spectrum of isolated compound 2 $\left(\mathrm{M}-\mathrm{H}^{+}\right.$and $\left.\mathrm{M}+\mathrm{H}^{+}\right)$are most abundant and characteristic peaks in flavonols. Compound 2 seems to be rutin as the mass fragmentation pattern and presence of base peak at $609.15\left(\mathrm{M}-\mathrm{H}^{+}\right)$ on matching with the existing literature increases the probability of the compound to be rutin.

Compounds $\mathbf{3}$ and $\mathbf{4}$ were isolated from the petroleum ether fraction of Kyllinga triceps from which the fatty acids were saponified using alcoholic $\mathrm{KOH}$ and the remaining extract was further purified with petroleum ether and subjected to column chromatography using gradient elution technique. Both compounds $\mathbf{3}$ and $\mathbf{4}$ gave positive tests for steroids and alcohols so it was assumed that compound contains steroid nucleus along with a alcoholic functional group attached to it. Both the compounds were found soluble in organic solvents like petroleum ether, benzene, dichloromethane, chloroform and methanol but insoluble in water.

Compound $\mathbf{3}$ is a white crystalline substance with melting point $160-166{ }^{\circ} \mathrm{C}$. The IR spectroscopic analysis showed the absorption band at $3337.9 \mathrm{~cm}^{-1}$, which is characteristic of $\mathrm{OH}$ stretching. Absorptions at $2962 \mathrm{~cm}^{1}$ and $2872 \mathrm{~cm}^{1}$ is due aliphatic $\mathrm{CH}$ stretching. Other absorption frequencies include $1453 \mathrm{~cm}^{1}$ as a result of bending frequency for cyclic $\left(\mathrm{CH}_{2}\right)_{\mathrm{n}}$ and $1374 \mathrm{~cm}^{1}$ for $\mathrm{OH}$ in plane bending vibration. The absorption frequency at $1054,965 \mathrm{~cm}^{1}$ signifies $-\mathrm{CH}$ out of the plane bending of cycloalkene. The out of plane $\mathrm{CH}$ vibration of unsaturated part was observed at $881 \mathrm{~cm}^{1}$. These absorption frequencies resemble the absorption frequencies observed for stigmasterol.

Compound 4 is a white crystalline substance with melting point $172-174{ }^{\circ} \mathrm{C}$. On subjection to IR spectroscopic analysis, the observed absorption bands are $3476 \mathrm{~cm}^{1}$ that is characteristic of $\mathrm{OH}$ stretching. Absorption at $2962 \mathrm{~cm}^{1}$ and 2831 $\mathrm{cm}^{1}$ is due aliphatic unsymmetrical and symmetrical CH stretching. Other absorption frequencies include $1653 \mathrm{~cm}^{1}$ as a result of $\mathrm{CH}=\mathrm{CH}$ stretching of unconjugated alkene showing a weak absorption band, $1453 \mathrm{~cm}^{1}$ bending vibration due to $-\mathrm{CH}_{2}$ scissoring vibrations, $1379 \mathrm{~cm}^{1}$ is due to $\mathrm{OH}$ in plane bending vibration. The absorption frequency at 1077 is due to $-\mathrm{C}-\mathrm{O}$ vibration of $-\mathrm{C}-\mathrm{OH}$ group, $953,837 \mathrm{~cm}^{1}$ signifies $-\mathrm{CH}$ in plane cyclo alkenes. These absorption frequencies resemble the absorption frequencies observed for $\beta$-sitosterol. In case of compound 3 the proton NMR showed the proton at C-3 appeared as a multiplet at $\delta 3.41$ and revealed the existence of signals for olefinic proton at C-6 $(\delta 5.28), \mathrm{C}-22(\delta 4.98), \mathrm{C}-23$ $(\delta 5.12)$, angular methyl proton at $\mathrm{C}-18(\delta 0.62), \mathrm{C}-19(\delta 1.18)$, were observed. In case of compound 4 the proton NMR showed the proton at C-3 appeared as a multiplet at $\delta 3.41$ and revealed the existence of signals for olefinic proton at C-6 ( $\delta 5.27)$, $\mathrm{C}=\mathrm{C}$ is not present in C-22 and C-23, so it can be easily distinguished from another compound $\mathbf{3}$ which have prominent peaks downfield due to olefinic protons in this position. Angular methyl proton at $\mathrm{C}-18(\delta 0.61), \mathrm{C}-19(\delta 1.18)$, were observed.

The ${ }^{13} \mathrm{C}$ NMR signals of compound 3 has shown recognizable signals 140.76 and 121.69 ppm, which are assigned C5 and C6 double bonds respectively as in $\Delta 5$ spirostene. The value at $19.39 \mathrm{ppm}$ corresponds to angular carbon atom (C19). Spectra show twenty nine carbon signal including six methyls, nine methylenes, eleven methane and three quaternary carbons. The other alkene carbons appeared at C-22 ( $\delta$ 138.3), C-23 $(\delta 129.29)$. The ${ }^{13} \mathrm{C}$ NMR signal of compound 4 has shown recognizable signals 140.78 and $121.68 \mathrm{ppm}$, which are assigned C5 and C6 double bonds respectively as in $\Delta 5$ spirostene which closely resembles compound $\mathbf{1}$. The value at $19.37 \mathrm{ppm}$ corresponds to angular carbon atom (C19). The values of C-22 ( $\delta 33.99), \mathrm{C}-23$ ( $\delta 26.19)$ differed from the compound $\mathbf{3}$ and thus proves that there is no double bond in the C-22 and C-23 position this is further strengthened by the ${ }^{1} \mathrm{H}$ NMR values at these carbons.

The weak molecular ions of compound $\mathbf{3}$ were given at $\mathrm{m} / \mathrm{z} 412$ and the characteristic peaks were given at $\mathrm{m} / \mathrm{z} 395$ that corresponds to $\left(\mathrm{M}^{+}-\mathrm{OH}\right)$. Other ion peaks are $\mathrm{m} / \mathrm{z}, 311$ due to $\left(\mathrm{M}^{+}-\mathrm{OH}-\mathrm{C}_{6} \mathrm{H}_{13}\right)$, peaks at 297,255 due to the formation of carbocation by $\beta$ bond cleavage of side chain leading to the loss of $\mathrm{C}_{7} \mathrm{H}_{14}$ and $\mathrm{C}_{10} \mathrm{H}_{19}$ from molecular ion $\mathrm{M}^{+}$, that corresponds to the $\mathrm{M}^{+} 115$ and $\mathrm{M}^{+} 157$. The molecular weight and fragmentation pattern indicate that the compound presenting this information is stigmasterol. The compound $\mathbf{4}$ on mass fragmentation gives a weak molecular ion peak $\mathrm{M}^{+}$at 414 which appear merged with 411, other prominent peaks appears at $m / z 297$ which is the base peak, most abundant fragment and is due to $\left(\mathrm{M}^{+} \mathrm{OH}\right)$, other peak at $\mathrm{m} / \mathrm{z}, 383$ and 257 are due to $\left(\mathrm{M}^{+}-\mathrm{OH}-\right.$ $\left.\mathrm{CH}_{3}\right)$ and $\left(\mathrm{M}^{+}-\mathrm{OH}\right)-\mathrm{C}_{10} \mathrm{H}_{21}$. The data of this compound sindicates that the compound is $\beta$-sitosterol.

Further confirmation of both the compounds $\mathbf{3}$ and $\mathbf{4}$ was achieved by conducting the HPLC. For the compounds $\mathbf{3}$ gradient elution was done with toluene and methanol using UV detector and the retention time of 6.08 min was obtained. For compound $\mathbf{4}$ isocratic elution was done using methanol: water (99:1), ELS detector was used due to weak chromophoric group in this compound ELSD (evaporative light scattering detection) conditions includes nebulized temp of $75^{\circ} \mathrm{C}$, evaporation temperature $90{ }^{\circ} \mathrm{C}$ and gas flow was maintained at 1.0 SLM (standard liters per min). The retention time of $3.02 \mathrm{~min}$ was obtained which was found to be reproducible.

From the findings of IR, ${ }^{1} \mathrm{H}$ NMR, ${ }^{13} \mathrm{C}$ NMR and MS spectral data and their comparison with those described in the literatures showed that, compound $\mathbf{3}$ was stigmasterol and compound 4 was $\beta$-sitosterol both of them were isolated from petroleum ether extract of the Kyllinga triceps and chemical 
structures elucidated respectively. It was carried out by means of various physical (solvent extraction, TLC, Column chromatography) and spectral techniques. The only difference found between the two compounds is the presence of $\mathrm{C} 22=\mathrm{C} 23$ double bond in Stigmasterol and C22-C23 single bond in $\beta$ sitosterol.

\section{Conclusion}

The study concluded the traditional use of the plant drug in the treatment of diabetes probably due to the isolated flavonoids i.e. quercetin, rutin and such other compounds.

\section{ACKNOWLEDGEMENTS}

The authors are thankful to Hon'ble Chancellor, Teerthanker Mahaveer University, Moradabad, India for providing the facility to carry out the research work.

\section{REFERENCES}

1. S. Hosseinzadeh, A. Jafarikukhdan, A. Hosseini and R. Armand, Int. J. Clin. Med., 6, 635 (2015); https://doi.org/10.4236/ijcm.2015.69084

2. M. Lahlou, Pharmacol. Pharm., 4, 17 (2013) https://doi.org/10.4236/pp.2013.43A003.

3. The Wealth of India, A Dictionary of Indian Raw Matrials and Industria Products, The Council of Scientific and Industrial Research, Vol. V: H-K, pp. 331-332, (2007)

4. K.M. Nadkarni, Indian Materia Medica, 1, 719 (2009).
5. C.P. Khare, Indian Medicinal Plant, 356 (2007)

6. S. Aneela, A. Dey and S. De, Int. J. Pharm. Life Sci., 5, 3385 (2014).

7. S. Sasidharan, Y. Chen, D. Saravanan, K.M. Sundram and L.Y. Latha, Afr J. Tradit. Complement. Altern. Med., 8, 1 (2011).

8. B. Sambandam, D. Thiyagarajan, A. Ayyaswamy and P. Raman, Int. J. Pharm. Pharm. Sci., 8, 120 (2016); https://doi.org/10.22159/ijpps.2016.v8i9.12288

9. Y.M. Musa, Int. J. Sci. Technol. Res., 4, 282 (2015).

10. Y. Zhu, Y. Liu, Y. Zhan, L. Liu, Y. Xu, T. Xu and T. Liu, Molecules, 18, 15648 (2013); https://doi.org/10.3390/molecules 181215648 .

11. V.S.P. Chaturvedula and I. Prakash, Int. Curr. Pharm. J., 1, 239 (2012); https://doi.org/10.3329/icpj.v1i9.11613.

12. W. Huang, C. Wan and S. Zhou, Trop. J. Pharm. Res., 12, 529 (2013); https://doi.org/10.4314/tipr.v12i4.13.

13. N. Sanghavi, S.D. Bhosale and Y. Malode, J. Sci. Innov. Res., 3, 594 (2014).

14. T. Seal, J. Appl. Pharm. Sci., 6, 157 (2016); https://doi.org/10.7324/JAPS.2016.60225.

15. T. Andrade-Filho, T.C.S. Ribeiro and J. Del Nero, Eur. Phys. J. E, 29, 253 (2009) https://doi.org/10.1140/epje/i2009-10485-7.

16. K.D. Bansod and P.P. Deohate, World J. Pharmacy Pharm. Sci., 4, 1132 (2015).

17. P.S. Pande and M.N. Mishra, Int. J. Chem. Phys. Sci., 4, 65 (2015)

18. F. Fathiazad, A. Delazar, R. Amiri and S.D. Sarker, Iran. J. Pharm. Res., 3, 222 (2006)

19. A. Kamboj and A.K. Saluja, Int. J. Pharm. Pharm. Sci., 3, 94 (2011).

20. P.S. Jain and S.B. Bari, Asian J. Plant Sci., 9, 163 (2010); https://doi.org/10.3923/ajps.2010.163.167.

21. V.A. Nyigo, X. Peter, F. Mabiki, H.M. Malebo, R.H. Mdegela and G. Fouche, The J. Phytopharmacol., 5, 100 (2016). 